\author{
ANTON A. ROVNER \\ Moscow State P.I. Tchaikovsky \\ Conservatory \\ Moscow, Russia \\ ORCID: 0000-0002-5954-3996 \\ antonrovner@mail.ru
}

\author{
A.A. POBHEP \\ Московская государственная \\ консерватория им. П.И. Чайковского \\ г. Москва, Россия \\ ORCID: 0000-0002-5954-3996 \\ antonrovner@mail.ru
}

\section{Vocal and Choral Symphonies and Considerations on Text Representation in Music}

The article examines the genres of the vocal and the choral symphony in connection with the author's vocal symphony Finland for soprano, tenor and orchestra set to Evgeny Baratynsky's poem with the same title. It also discusses the issue of expression of the literary text in vocal music, as viewed by a number of influential 19th and 20th century composers, music theorists and artists. Among the greatest examples of the vocal symphony are Gustav Mahler's Das Lied von der Erde and Alexander von Zemlinsky's Lyrische Symphonie. These works combine in an organic way the features of the symphony and the song cycle. The genre of the choral symphony started with Beethoven's Ninth Symphony and includes such works as Mendelssohn's Second Symphony, Scriabin's First Symphony and Mahler's Second, Third and Eighth Symphonies. Both genres exemplify composers' attempts to combine the most substantial genre of instrumental music embodying the composers' philosophical worldviews with that of vocal music, which expresses the emotional content of the literary texts set to music.

The issue of expressivity in music is further elaborated in examinations of various composers' approaches to it. Wagner claimed that the purpose of music was to express the composers' emotional experience

\section{Вокалыные и хоровые симфонии и размышления о представлении текста в музыке}

\author{
В статье рассматриваются жанры \\ вокальной и хоровой симфоний в связи \\ с написанной автором статьи вокальной \\ симфонией «Финляндия» для сопрано, \\ тенора и оркестра на стихотворение \\ Е. Баратынского. Также обсуждается \\ проблема выражения литературного \\ текста в вокальной музыке с точки зрения \\ нескольких знаменитых композиторов, \\ теоретиков и художников XIX и XX веков. \\ Среди самых известных вокальных \\ симфоний следует упомянуть Песнь \\ о земле Г. Малера и Лирическую симфонию
} А. фон Цемлинского. Эти два сочинения органически сочетают черты симфонии и вокального цикла. Жанр хоровой симфонии с голосами возник начиная с Девятой симфонии Бетховена. К нему относятся Вторая симфония Мендельсона, а также Вторая, Третья и Восьмая симфонии Малера. Оба жанра представляют стремление композиторов сочетать самый значительный жанр инструментальной музыки - симфонический, - выражающий мировоззрение композиторов, с жанром вокального цикла, передающим эмоциональное содержание положенных на музыку литературных текстов. Вопрос выразительности в музыке далее рассматривается через сравнение подходов к нему разных композиторов. Вагнер утверждал, что цель музыки - выражение эмоционального опыта композитора 
and especially the literary texts set to music. Stravinsky expressed the view that music in its very essence is not meant to express emotions. He called for an emotionally detached approach to music and especially to text settings in vocal music. Schoenberg pointed towards a more introversive and abstract approach to musical expression and text setting in vocal music, renouncing outward depiction for the sake of inner expression. Similar attitudes to this position were held by painter Wassily Kandinsky and music theorist Theodor Adorno. The author views Schoenberg's approach to be the most viable for 20th and early 21st century music.

\section{Ключевые слова:}

vocal symphonies, choral symphonies, the symphonic genre, expression in music, Mahler, Zemlinsky, Wagner, Stravinsky, Schoenberg, Kandinsky, Adorno. и, в особенности, вдохновляющих его литературных произведений, положенных на музыку. Стравинский считал, что музыка по своей сути не предназначена выражать чувства. Он призывал к эмоционально абстрагированному подходу к музыке и особенно к выражению в ней литературного текста. Шёнберг указывал на более интровертивную и абстрактную манеру выразительности в музыке и выражения в ней литературных текстов, когда происходит отказ от внешней изобразительности в пользу глубинного выражения. Подобные взгляды на этот вопрос наблюдаются у художника В. Кандинского и музыкального теоретика Т. Адорно. Автор статьи считает подход Шёнберга наиболее действенным для музыки XX и начала XXI веков.

Keywords:

вокальные симфонии, хоровые симфонии, симфонический жанр, выражение в музыке, Малер, Цемлинский, Вагнер, Стравинский, Шенберг, Кандинский, Адорно.

Для цитирования/For citation:

Anton A. Rovner. Vocal and Choral Symphonies and Considerations on Text Representation in Music // ICONI. 2020. No. 2, pp. 27-37 DOI: 10.33779/2658-4824.2020.2.026-037

\section{Vocal Symphonies}

The genre of the vocal symphony has a brief but distinguished history during the last two centuries. There has been a number of important attempts to combine the forms of large symphonic orchestral works with the genre of a vocal composition. These attempts include the genre of the vocal symphony as well as near-related genres such as cantatas, oratorios, other various types of religious music, and standard symphonies which include voices - soloists or choruses, in either brief sections or entire movements. Among the famous compositions written in the genre of the vocal symphony, mention must be made first of all of Gustav Mahler's Das Lied von der Erde, a six-movement work for alto, tenor and orchestra, as well as Alexander von Zemlinsky's Lyrische Symphonie, a seven-movement composition for soprano, baritone and orchestra. Works written in nearly related forms include cantatas for soloists, chorus and orchestra, among which mention first of all must be made of When Lilacs Last in the Dooryard Bloom'd by Roger Sessions and Il Canto Sospeso by Luigi Nono. Some of the works include chamber ensembles, as opposed to orchestras, yet carry a symphonic type of development; among these one can name Gradus ad Parnassum for soprano, large chamber ensemble and electronic sounds by Rolv Yttrehus, as well as A Winter's Tale for soprano and chamber ensemble by Charles Wuorinen. 


\section{Das Lied von der Erde and Lyrische Symphonie}

The two most famous compositions which can be called vocal symphonies are Gustav Mahler's Das Lied von der Erde, composed in 1908, and Alexander von Zemlinsky's Lyrische Symphonie, composed in 1922. Both are characteristic for their combination of the symphonic genre with vocal genres, since they are large orchestral compositions of symphonic scope and symphonic development, to which a second element is added, namely, the voice - which usually pertains to rather distant and nearly antipodal genres. The two elements placed together form a heterogeneous type of duality in these compositions, namely, the antithesis of pure, "absolute" symphonic thought and the "programmatic" vocal writing which aims at describing literary events taking place in the text to which the music is set. In these two works, these two contrasting elements of music, those of instrumental and vocal development are combined. Gustav Mahler's Das Lied von der Erde, written for two solo singers and orchestra, is a setting of German translations of six poems by ancient Chinese poets. There are six separate movements, which are contrasting in tempo and mood, each one featuring a setting of one poem (or, in the case of the last movement, of excerpts of two poems). Though originally these poems were not at all related to each other, Mahler chose them out of many others and combined them in a particular order to create a complete literary and dramatic context for the whole composition. In a sense, this arrangement builds up into a unified narrative which relates directly to Mahler's own experience. The tenor and alto sing as soloists alternately with each other, each one predominating through an entire movement before passing the following movement to the other soloist.

Alexander von Zemlinsky's Lyrische Symphonie, likewise written for two soloists and orchestra, is a musical setting to German translations of poems by Indian poet
Rabindranath Tagore. In Zemlinsky's own words, the work belongs to the tradition of Mahler's Das Lied von der Erde. Unlike Mahler, who took the poems of several poets for his composition, Zemlinsky chose the poetry of one poet, providing a more unified literary background to the composition. Whereas Mahler achieved a synthesis of Chinese poetic traditions and a European musical language with a minimum of stylization of Chinese music, Zemlinsky combined Indian poetry with European musical traditions in a way that implicated Indian music directly. Also, unlike Das Lied von der Erde, the texts of the poems in Zemlinsky's work, though related to each other in their style and overall mood, do not create an impression of a narrative or a story in the manner of Mahler's work, but form a compilation of sketches and impressions of certain moods, which connect to each other in a more remote manner. The composition's seven movements have very contrasting tempi and moods and are played one after the other without a break. The individual movements are joined by orchestral interludes, which gives the work the form of a large one-movement symphony of compound form - following more along the stylistic tradition of Schoenberg's First String Quartet and First Chamber Symphony. Similar to Das Lied von der Erde, the Lyrische Symphonie features the male and female voices singing as soloists alternately with each other, each soloist singing through an entire movement, before the other soloist takes on the following movement.

There is a direct connection between these two works and my composition, Finland for soprano, tenor and orchestra set to a poem by Evgeny Baratynsky, which in its own individual way follows the traditions of both compositions. Unlike the two previous works, Finland is a setting of one longer poem which is comprised of six stanzas. These stanzas provide the six sections which make up the composition; these are played one after another without interruption, similarly to the Lyrische Symphonie. I did not have to compile a narrative of six 
or seven unrelated poems, since in the one poem I have chosen the narrative already exists, as it was formed by the poet. As in the two preceding works, Finland presents the two soloists independently, alternating with each other in each successive section, each soloist singing through an entire section before passing to the other soloist in the following section. In two sections of Finland I have provided for a sharp deviation from the tradition of the previous two compositions by inserting two duets at the end of the third and sixth sections.

One other feature which distinguishes Finland from the last two named works, while Mahler's work contains allusions to Chinese music, and Zemlinsky's music alludes to Indian music, my composition does not contain any direct references to Russian or Finnish music, whether the folk or the classical musical tradition, and does not contain any national traits of the music of these countries, except, perhaps, the emotional breadth of the orchestral writing. The title of my composition, Finland, gives allusions to Sibelius' Finlandia. Nevertheless, the musical language of my composition is rather remote from that of Sibelius and does not contain any direct influence of the latter, although some of the results which I have achieved in the orchestration and emotional flavor have unintentionally come close to those of Sibelius' music, especially in the broad orchestral passages, which give prominence either to the brass or to the string instruments.

\section{Symphonies with Voices and Program music}

Mahler's Das Lied von den Erde and Zemlinsky's Lyrische Symphonie had a history of precedents which led up to the formation of the genre in which the two works are written. There have been several cases of added vocal lines to standard symphonies from the 19th centuries onwards, the aim of which was to strengthen and expand the programmatic and literary elements of the symphonic genre and turn it from its standard role, which it had in the 18th century, of a large abstract genre based on an established form and containing a number of contrasting movements, as well as a number of diverse themes and moods. This distinctive feature helped turn the genre of the symphony further in the direction of a near-literary dramatic work which is meant to convey messages of distinct contrasting moods and to imply hidden philosophical messages meant to be entrusted to the listener, so that the latter would interpret them.

One of the first and most prominent examples of adding the voice to the symphony was Beethoven's Ninth Symphony. In the finale of this work sonata form which was frequently used in fourth movements of Classical symphonies made way for a musical setting of Friedrich Schiller's "Ode to Joy” for chorus and orchestra, preceded by a theatrical, almost programmatic introduction, which features a conflict and resolution of thematic material from the symphony's preceding movements. This was a major innovation in the genre of the symphony. It paved the way for further attempts to add literary and programmatic implications to the symphony. Wagner in several of his books and essays, including Opera and Drama and The Art Work of the Future, claimed that after Beethoven's Ninth Symphony the symphonic form was obsolete, and so was "absolute music." Wagner claimed that Beethoven with the means of his setting of the "Ode to Joy" in the Ninth Symphony had led the history of the symphony to its logical and triumphant conclusion and completion and opened the doors to program music, which was the "Music of the Future"; the latter music was forever freed from the shackles of traditional classical forms, especially the sonata form, ad granted the privilege of wholeheartedly conveying contrasting emotions to form narrative events. According to Wagner, the future of music was no longer in traditional instrumental musical genres, but in largescale theatrical and operatic works which 
utilized voices and orchestra and did not adhere in the least to any formal or structural scheme. Other composers have gone in that direction to a greater or lesser extent, yet virtually none of them have superseded Wagner in the programmatic character of his music, which stemmed from his revolutionary ideas of the new role of music after Beethoven.

This is what Wagner writes in his large essay The Art Work of the Future concerning the future of music, the duty of which, he claims, is to connect itself with two other arts, namely, Dance and Poetry, to produce the Gesamtkunstwerk, which is to be the opera: "The Last Symphony of Beethoven is the redemption of Music from out her own particular element into the realm of universal Art. It is the human Evangel of the art of the Future. Beyond it no further step is possible; for upon the perfect Art-work of the Future alone can follow, the universal Drama to which Beethoven has forged to us the key... Thus has Music of herself fulfilled what neither of the sacred arts had skill to do. Each of these arts but eked out her own selfcentered emptiness by taking, and egoistic borrowing; neither, therefore, had the skill to be herself, and of herself of herself to weave the girdle wherewith to link the whole. But Tone, in that she was herself completely, and moved amid her own unsullied element, attained the force of the most heroic, most loveworthy self-sacrifice, - of mastering, nay of renouncing her own self, to reach of to her sisters the hand of rescue" [8, pp. 126-127].

Among the more traditional composers, one can cite Mendelssohn, who included parts for chorus and soloists in the finale of his Second Symphony, known as Der Lobgesang, continuing Beethoven's tradition of conveying a more programmatic message in his symphonies, adding the latter to the more traditional symphonic form to which he continued to adhere.

A more innovative approach to the symphonic genre, closer to Wagner's position on operas, was taken by Franz Liszt in his two symphonies inspired by literature, the Dante Symphony and the Faust Symphony. Both works are symphonies in name more than in their genre, since they are primarily programmatic works, which focus more on conveying emotions arising from literary works rather than following traditional symphonic forms. The Faust Symphony retains the symphonic form to a slightly greater degree, merging it successfully with the depiction of literary events. Both symphonies finish with codas, which involve choruses and soloists. The inclusion of musical text settings at the end of both symphonies strengthens the roles of the symphonies' literary plots and shows them as clearly dominating over the purely instrumental, formal aspects of the works. The Dante Symphony is based on Dante's Divine Comedy and consists of two movements, which depict the three sections of Dante's work, namely, "Hell," depicted in the symphony's first movement, and "Purgatory" and "Paradise," both depicted in the symphony's second movement.

The next important composer who successfully combined the symphony with the voice was Gustav Mahler. In four of his symphonies, the Second, Third, Fourth and Eighth, he included vocal lines to the orchestral writing, strengthening the programmatic character of these works. The Second Symphony involves a soprano in the fourth movement (singing a song from the collection of Des Knaben Wunderhorn) and then chorus and soloists in the final section of the fifth movement, which depicts the resurrection of the dead and their ultimate transfiguration. The Third Symphony has two vocal movements: the fourth movement, in which the soprano sings a setting of a text from Friedrich Nietzsche's Also Sprach Zarathustra, and the fifth movement, which features a chorus singing a setting of a humorous poem from the Des Knaben Wunderhorn collection about a child's vision of heaven. The Eighth Symphony is Mahler's finest achievement in the domain of symphony with vocal parts; it features vocal settings in its entirety. Its first movement is 
a setting of a Medieval Latin hymn "Veni Creator Spiritus," the emotional spirit of which organically merges with the formal structure of Mahler's extremely extended interpretation of sonata form. The second movement, which takes up about two thirds of the entire symphony, is a setting of the entire final scene of Goethe's Faust, Part $I I$, taking place in heaven. The movement combines in itself three movements of the classical symphony - the Adagio, the Scherzo and the Finale - into one long continuous movement. The conjunction of three movements merged into one, along with the dramatic succession of emotional moods, characters and events of the final scene of Faust, forms one of the most outstanding qualities of this symphony.

Finally, mention must be made of an example of incorporating vocal writing into an instrumental chamber work, the aim of which is to strengthen the latter's programmatic character. Arnold Schoenberg's Second String Quartet in F\# Minor consists of four movements, two of which, the third and the fourth, contain soprano settings of two poems by German Expressionist poet Stefan George, entitled, respectively, "Litanei" ["Supplication"] and "Entrückung" ["Awakening”]. The poems of George and the vocal writing in the quartet greatly enhance the emotional, expressionistic qualities of the composition and bring its programmatic qualities to the foreground. After the lamenting the first movement and the grotesque and morbidly ironic second movement, the third movement opens with the setting of the George poem "Litanei" in an extremely intricate and elaborate combination of a lamenting text and highly emotional music. the text brings out and emphasizes the emotional message of the string quartet's first three movements, which until now could only be intimated by the listener. The fourth movement provides an emotional relief from the morbid mood of the first three movements by depicting a state of enlightenment and transfiguration, as emphasized by the text of the poem, entitled "Entrückung." The text describes the spiritual awakening of the poet to a higher existence and the dissolution of his previous state of anxiety. The music clearly follows the mood conveyed by the poem by depicting an exalted, enlightened emotional state. It uses non-standard and innovative textural means to do so; and it also provides a landmark in Schoenberg's musical legacy as the first work of his to employ atonality.

\section{Considerations \\ on Text Representation in Music}

The question of the validity of attaching programmatic tags to purely musical development has presented a lasting controversy throughout the history of music, and especially during the last two centuries, staring from the advent of the Romantic era. On the one hand, many musicians claimed that the chief aim of music was to convey emotion, either of a written text, with or without its actual statement in the vocal line, or of the composer's personal emotional life and strivings for the ideal. Other musicians held the opposite view, stating that music cannot really express any emotions, nor depict any literary events. Igor Stravinsky in his two books Autobiography and Poetics of Music wrote that music by its very nature cannot depict any emotions at all, since music is merely a succession of notes, scales, rhythms and other elements which are constructed in a certain way in order to produce a musical composition. This is what Stravinsky writes in his Autobiography: "I consider that music is, by its very nature, essentially powerless to express anything at all, whether a feeling, an attitude of mind, a psychological mood, a phenomenon of nature, etc. Expression has never been an inherent property of music. that is by no means the purpose of its existence. If, as is nearly always the case, music appears to express something, this is only an illusion and not a reality... The phenomenon of music is given to us with the sole purpose of establishing an order in things, including 
and particularly, the coordination of man and time. To be put into practice, its indispensable and single requirement is construction. Construction once completed, this order has been attained, and there is nothing more to be said... People will always insist upon looking in music for something that is not there. The main thing for them is to know what the piece expresses, and what the author had in mind when he composed it. They never seem to understand that music has an entity of its own apart from anything it may suggest to them" [6, p. 38].

In his book Poetics of Music, Stravinsky gives a more moderate view, acknowledging the presence of emotional associations in music, but prescribing to them a role of secondary importance: "I have no thought of denying to inspiration the outstanding role that has developed upon it in the generative process we are studying; I simply maintain that inspiration is in no way a prescribed condition of the creative act, but rather a manifestation that is chronologically secondary.

...It is afterwards, and only afterwards, that the emotional disturbance which is at the root of inspiration may arise - an emotive disturbance about which people talk so indelicately by conferring upon it the meaning that is shocking to us and that compromises the term itself. Is it not clear that this emotion is merely a reaction on the part of the creator grappling with that unknown entity which is still only the object of his creating and which is to become a work of art? Step by step, link by link it will be granted to him to discover the work" [7, p. 50].

A very good example of a less emotional approach to text setting is Stravinsky's Symphony of Psalms, a work in three contrasting movements for chorus and orchestra that features a setting of three Psalms in Latin. Stravinsky himself pointed out that the advantage of setting a text in Latin, as opposed to a modern language, was to have a more remote and less personal approach to the text, so that the music would not be pictorially descriptive of the text or melodramatic, but would be more independent of the text and conscious of its own inherent form. As a result, Stravinsky's Symphony of Psalms contains a semantical connection between the words and the music, yet becomes successfully free from excessive pictorialism and the word painting inherent in the works of many late Romantic composers. Other vocal works of Stravinsky, including such works as Les Noces and Mavra, contain many theatrical effects and exoticism derived from Russian folk music. rather than following the written text in their format, they treat the text in an experimental manner as a tool, frequently resorting to linguistic experiments, such as change of stress in a given word. Notwithstanding this avoidance of a programmatic approach to text setting, these compositions, as well as other vocal works by Stravinsky succeed in giving adequate musical representations of the texts.

Still other musicians paved a middle ground between these two opposite views concerning text setting, those of Wagner and Stravinsky. Theodor W. Adorno in his first essay of his book Quasi una Fantasia, Essays on Modern Music gave a very thorough analysis of the practical role of music. he acknowledged the emotional capabilities of music, yet he claimed that, nevertheless, music cannot be placed in a position of clearly describing verbatim a written text or an extra-musical entity in a way that literature or the visual arts can. Adorno pointed out that music has capabilities of expressing more than words can ever convey, including even deeper and subtler emotions than can ever be accounted by the spoken or written word, but still it can never be placed on an identical level with a text. This he acknowledged to be a deprivation of music, while from a different angle he claimed it to be an advantage. This is what he writes: "Music aspires to be a language without intention. But the demarcation line between itself and the language of intentions is not absolute: we are not confronted by two wholly separate realms. There is a dialectic 
at work. Music is permeated through and through with intentionality... Music bereft of all intentionality, the merely phenomenal linking of sounds, would be an acoustic parallel to the kaleidoscope. On the one hand, as absolute intentionality it would cease to be music and would effect a false transformation into language. Intentions are central to music, but only intermittently. Music points to true language in the sense that content is apparent to it, but does so at the cost of unambiguous meaning, which has migrated to the languages of intentionality. And as though Music, that most eloquent of all languages, needed consoling for the curse of ambiguityits mythical aspect, intentions are poured into it. 'Look how it constantly indicates what it means and determines it.' But its intentions also remain hidden” [1, pp. 2-3].

One of the most striking approaches to text setting was elaborated by two authors in the Expressionistic artistic almanac Der Blauer Reiter, published in Berlin in 1912. The first of these authors was Arnold Schoenberg, who contributed to the almanac with an essay entitled "Concerning Text Setting in Music" (subsequently published in the collection of Schoenberg's articles, titled Style and Idea). In this article Schoenberg cautions against excessive outward expression of the written text when setting it to music. he writes that when a composer follows a text too literally and depicts every word, the music ceases to have an organic growth and development of its own and breaks the laws of musical syntax and coherence when it follows the development of the text, instead of its own. Distancing oneself from the text and following the development of the music itself, while grasping the main idea or mood of the text, will develop a deeper kind of inner expression of the text, as opposed to a more superficial outward depiction. Schoenberg wrote that when once he composed a song on a given poem, he was inspired by the mood of the poem's first few lines, after which he divorced himself completely from the poem and continued to develop the musical material with which he started the song, guiding himself merely by some of the phonetic sounds of the poem for greater structural coherence. Upon finishing the song, Schoenberg claims that he discovered for himself that he was much more successful in grasping the inner mood and spirit of the poem than if he had adhered to the written text more literally.

"I had composed many of my songs straight through to the end, without troubling myself in the slightest about the continuation of the poetic events, without even grasping them in the ecstasy of composing, and that only days later I thought of looking back to see just what was the real poetic content of my song. It then turned out, to my greatest astonishment, that I had never done greater justice to the poet, than when, guided by my first direct contact with the sound of the beginning, I divined everything that obviously had to follow the first sound with inevitability" [5, p. 144].

The second of the two mentioned authors in the Der Blauer Reiter almanac was the famous Russian abstract painter Wassily Kandinsky. Kandinsky contributed several articles to the almanac in which he presented some of the most important theoretical concepts of the newly emerging Expressionist art. Kandinsky claimed that the means of expression for the old art and the new art were complete opposites. The means of expression for traditional art was literally depicting real objects and describing emotions and dramatic events as they happened or were supposed to happen. The means of expression of new art was shedding the literal material description of events and following a more inward, spiritual expression of objects or entities, which, at first appearance, might entirely contradict them in terms of literal depiction. Nevertheless, this new form of expression describes a given emotion or event more thoroughly by grasping its spiritual essence. The famous painter provided respective formulas for the two trends of art, the old and the new, which gave an adequate 
representation of their respective functions of description of emotions or events. Thus, the formula for the old type of art is: $1+1=2$, while the characterization of the new form of art is: $1-1=2$. The formula for the new form of art provides a very clear and concise description of the means of expression in the new form of art: by taking away from the descriptive means of the outward, superficial events of a narrative, the artist contributes to the hidden, inner meaning of the events and gives a deeper description of emotions inherent in the work of art. This is how some of the first foundations of the new type of art and the new means of expression were created.

This is what Kandinsky writes in his article "On Stage Composition": "The nineteenth century is distinguished as a period that lay far from inner creation. Its concentration on material appearances and on the material aspects of appearances logically caused internal creative powers to decline to the point of their virtual disappearance...

The positive character of the spirit of the timer could lead only to a point of combination that was likewise positive. People thought: two is more than one, and they tried to strengthen each effect by repeating it. With inner effects this may be reversed, and often one is more than two. In mathematics $1+1=2$. In the soul it is possible that $1-1=2 \ldots$

Wagner tried to intensify the means and bring the work to a monumental height by repeating one and the same external movement in two concrete forms. His mistake was to believe that he had a universal method at his command. Actually, his method was only one of a series of even more powerful possibilities of monumental art....

The logical result of this is the limitation, the one-dimensionality (impoverishment) of forms and methods. Gradually they became orthodox and each tiny change becomes revolutionary...

Let us start on the basis of the internal. The whole state of affairs changes fundamentally.
Suddenly the external appearance of each element vanishes, and its inner value sounds fully.

Clearly, when the criterion of the inner sound is applied, the outer action obviously is not only unimportant, but also creates harmful obscurity.

The external connection appears in its proper value, i.e., setting up unnecessary limits and weakening the inner effect.

Automatically the feeling of necessity of internal unity is aroused. This is supported and even caused by external irregularities.

It opens up the possibility for each element to keep its own external life, even if it contradicts the external life of another element” [2, pp. 192-201].

In his second article, "The Question of Form," Kandinsky develops the idea further: "The 'artistic' reduced to a minimum must be considered as the most intensely effective abstraction.

Footnote: The quantitative reduction of the abstract therefore equals to the qualitative intensification of the abstract. Here we touch one of the most essential rules: the external enlargement of a means of expression leads under certain circumstances to the reduction of its internal power. Here $2+1$ is less than $2-1 \ldots$ In short: true form is produced from the combination of feeling and science" [3, pp. 162-163].

This new approach to expression in art was shared by many composers and other artists of the time. Schoenberg himself claimed that his discovery of atonality helped him disclose for himself a whole array of new moods which had not been available or fit for description in the traditional major-minor system. This is especially well manifested in his monodrama Erwartung for soprano and large orchestra, set to a text about a woman looking for her lover in the forest at night and finding him dead. The woman goes through a whole series of emotions, which the music tries to describe dramatically by using its new atonal language, since the emotions described in the text are of too wide a variety to be limited to major and minor. 
Further developments in the 20th century have increased the technical capabilities of music and with those, the means of arousing an emotional response in the listeners by ever-increasing varieties of new and unusual techniques and sound effects. It follows that there have been more varied and contrasting approaches to text setting and the relationship to the text, as well as the opposition of attempting to describe the written text in the music and concentrating on the purely musical development in a vocal musical composition, using the text merely as a foundation. In the latter part of the 20th century there has also been an increased attention to the pure phonetic capabilities of language, and written texts have been treated as sound palettes which connected with and complemented the sound palettes of the music. Often composers have exploited the approach by emphasizing isolated syllables with their phonetic sound possibilities, as opposed to paying attention to complete works.

My view of the situation follows those of Adorno and the two contributors to Der Blaue Reiter, Schoenberg and Kandinsky, which I feel are the closest to meeting the aesthetic requirements of the late 20th and early 21st century. Just as the beginning of the 20th century gave us a totally new outlook on harmony, as well as on formal organization, many important composers and music theorists today are continuing to develop and enhance its evolution, which stems from Classical and Romantic harmony and form. Likewise, the approach to the relationship of music and text cannot remain within the aesthetic realm of the 19th century. The utopian ideas of Wagner of turning music into a servant of the text have a place in the historical evolution of music, but cannot be followed literally in the present day, as music has its own development which cannot be reduced to developing the verbal text. In contrast to 19th-century Romantic aesthetics, which advocated an unrestrained outpouring of a highly emotional musical syntax, 20th century aesthetics demand considerably more moderation of emotions, declining to express the text "literally" and concentrating on aspects of form and logical coherence, not to mention new textural and timbral possibilities. Just as there has evolved a more abstract approach to text in literature and to forms in painting and sculpture, the "old type of expression,” which features literal depiction of extra-musical subject matter, as well as pictorialism, must give way to a more abstract, ambiguous relationship between textual meeting and the shape of a completed work of art. Avoidance of the literal, the pictorial, and the standard accepted associations of expression of emotions lead to a new syntactical type of meaning virtually devoid of extra-musical relationship. As Schoenberg writes: "There are relatively few people who are capable of understanding purely in terms of music, what music has to say. The assumption that a piece of music must summon up images of one sort or another, and that if those are absent the piece of music has not been understood or is worthless, is as widespread as only the false and banal can be. Nobody expects such a thing from any other art, but rather contents himself with the effects of its material, although in the other arts the material-subject, the represented object, automatically presents itself to the literal power of comprehension of the intellectually mediocre. Since music as such lacks a material-subject, some look behind its effects for purely formal beauty, other seek poetic procedures” [5, p. 141].

Stravinsky in his Poetics of Music comes to a concise conclusion in regards to this subject: "What is important for the lucid ordering of the work - for its crystallization - is that all the Dyonisian elements which set the imagination of the artist in motion and make the life-sap rise must be properly subjugated before they intoxicate us, and must finally be made to submit to the law: Apollo demands it” [7, pp. 80-81].

Stravinsky's anti-Romantic polemic, though an important step in overcoming the 
excessively literal pictorialism in music, as well as other arts in his time, has by now been superseded. It has been said that had Schoenberg, Stravinsky and other early 20 th century composers not discovered their respective individual, innovative styles which countered the Romantic movement, then the many innovations and modes of dramatic and pictorial expression found in the musical compositions of Wagner, Mahler and Richard Strauss would gradually have degenerated into a superficial pictorialism, and the entire Western classical musical tradition would have sunk to the level of movie music. Nevertheless, in the close of the 20th century, as the danger of excessive pictorialism in music has been overcome, it is not necessary any more to distance oneself entirely from attempting to tie the semantic meaning of the music with that of the text. It is as worthy and challenging a task now as it was in previous periods of musical history to probe the meaning of the text and attempt to link it with the structural and semantic possibilities of one's musical language in order to create a meaningful musical composition which combines text and music in order to create an adequate emotional response In the listeners, achieving a balance between abstract form and representation of the text can enhance the development of vocal music. As Adorno writes in his previously mentioned article: "Music is more than intentionality, but the opposite is no less true: there is no music which is wholly devoid of expressive elements. In music even nonexpressiveness becomes expressive... Every musical phenomenon points to something beyond itself by reminding us of something, contrasting itself with something or arousing our expectations. The summation of such a transcendence of particulars constitutes the 'content'; it is what happens in music... Music becomes meaningful the more perfectly it defines itself in this sense - and not because its particular elements express something symbolically. It is by distancing itself from language that its resemblance to language finds its fulfillment" [1, p. 6].

A viable approach for vocal music today is one which successfully combines a sound, complex form, following purely musical laws, and a text setting that avoids the dangers of literal representation: a more distanced manner, following the maxims of Kandinsky in his call for "new expression in art." Experiments in emphasizing a text's phonetical possibilities as a medium of sound, as well as developments in combining voice and electronic music have contributed to a balance between the opposing approaches. As Schoenberg writes in his article "Heart and Brain in Music": "It is not the heart alone which creates all that is beautiful, emotional, pathetic, affectionate, and charming; nor is it the brain alone which is able to produce the well-constructed, the soundly organized, the logical and the complicated. First, everything of supreme value in art must show heart as well as brain. Second, the real creative genius has no difficulty in controlling his feelings mentally; nor must the brain produce only the dry and unappealing while concentrating on correctness and logic” [4, p. 85].

Among those important 20th century works which have successfully accomplished the task of combining pure musical form with a fair representation of the text one can name Anton Webern's cantata Die Augelicht, as well as his two chamber cantatas, opus 29 and opus 31; Le Marteau sans Maitre for soprano and chamber ensemble by Pierre Boulez; Karlheinz Stockhausen's Gesang der Junglinge for electronic sounds, which uses a processed recording of a boy singing a Biblical text; Luigi Nono's Il Canto Sospeso for chorus and orchestra; Milton Babbitt's Philomel for voice and electronic sounds; Rolv Yttrehus' Gradus ad Parnassum for chamber ensemble and electronic sounds and Charles Wuorinen's A Winter' Tale. All of these works have elaborate structural schemes, but also do justice to serving the text and to arousing emotional responses in the listeners. 
Although my composition Finland stems from the tradition of Mahler's Das Lied von der Erde and Zemlinsky's Lyrische Symphonie and has to a certain degree derived from them an approach to Romantic discourse, it also meets the need to connect with the emotional mood of Evgeny Baratynsky's poem "Finland." I have aimed at achieving a less programmatic and more abstract musical syntactical language, avoiding literal depiction of the text and the emotional mood conveyed in it by distancing myself from overly direct pictorialism and trying to achieve a type of expression corresponding to Kandinsky's concept of "new" and "inner expression." I have also paid close attention to following purely musical laws of development independent of the elaboration of the subject matter of the poem. My aim from this perspective has been to build a complex and elaborate formal structure both in the large-scale form and in the smaller-scale thematic, motivic and serial dimensions.

\section{e REFERENCES}

1. Adorno, Theodor W. Music and Language: A Fragment. Quasi una Fantasia, Essays on Modern Music. Translated by Rodney Livingstone. London and New York: V. Verso, 1992. 348 p.

2. Kandinsky, Wassily. On Stage Composition. Der Blaue Reiter Almanac, The Documents of 20th Century Art. Edited by Wassily Kandinsky and Franz Marc. New Documentary Edition edited and with an introduction by Klaus Lankheit. New York. The Viking Press. 1974. 296 p.

3. Kandinsky, Wassily. On the Question of Form. Der Blaue Reiter Almanac, The Documents of 20th Century Art. Edited by Wassily Kandinsky and Franz Marc. New Documentary Edition edited and with an introduction by Klaus Lankheit. New York. The Viking Press. 1974. 296 p.

4. Schoenberg, Arnold. "Heart and Brain in Music." Style and Idea: Selected Writings of Arnold Schoenberg. Edited by Leonard Stein. London. Faber \& Faber. Berkeley and Los Angeles. University of California Press. 1975, pp. 53-76.

5. Schoenberg, Arnold. The Relationship to the Text. Style and Idea: Selected Writings of Arnold Schoenberg. Edited by Leonard Stein. London. Faber \& Faber. Berkeley and Los Angeles. University of California Press. 1975, pp. 141-145.

6. Stravinsky, Igor. An Autobiography. New York: M. \& J. Steuer. 1958. 176 p.

7. Stravinsky, Igor. Poetics of Music. Translated by Arthur Knodel and Ingolf Dahl. Cambridge, Massachussetts: Harvard University Press, 1975. 142 p.

8. Wagner, Richard. The Art Work of the Future. The Art Work of the Future and other Works. Translated into English by W. Ashton Ellis. Lincoln and London: University of Nebraska Press, 1993. $422 \mathrm{p}$.

About the author:

Anton A. Rovner, Ph.D. (Arts), Cand. Sci. (Arts), Faculty Member at the Department of Interdisciplinary Specializations for Musicologists, Moscow State P.I. Tchaikovsky Conservatory (125009, Moscow, Russia),

ORCID: 0000-0002-5954-3996, antonrovner@mail.ru

Об авторе:

Ровнер Антон Аркадьевич, Ph.D., кандидат искусствоведения, преподаватель кафедры междисциплинарной специализации музыковедов, Московская государственная консерватория им. П.И. Чайковского (125009, г. Москва, Россия), ORCID: 0000-0002-5954-3996, antonrovner@mail.ru

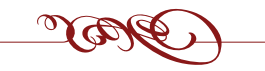

